\title{
Assessing the interaction between mountain forests and snow avalanches at Nevados de Chillán, Chile and its implications for ecosystem-based disaster risk reduction
}

\author{
Alejandro Casteller ${ }^{1,2}$, Thomas Häfelfinger ${ }^{1}$, Erika Cortés Donoso ${ }^{3}$, Karen Podvin ${ }^{3}$, Dominik Kulakowski ${ }^{4}$, and \\ Peter Bebi ${ }^{1}$ \\ ${ }^{1}$ WSL Institute for Snow and Avalanche Research SLF, Davos Dorf, Switzerland \\ ${ }^{2}$ Instituto Argentino de Nivología, Glaciología y Ciencias Ambientales IANIGLA, \\ CCT-CONICET-Mendoza, Mendoza, Argentina \\ ${ }^{3}$ IUCN, International Union for Conservation of Nature - Regional Office for South \\ America, Quito, Ecuador \\ ${ }^{4}$ Graduate School of Geography, Clark University, Massachusetts, USA
}

Correspondence: Alejandro Casteller (acasteller@hotmail.com)

Received: 2 October 2017 - Discussion started: 17 November 2017

Revised: 15 March 2018 - Accepted: 25 March 2018 - Published: 18 April 2018

\begin{abstract}
Gravitational natural hazards such as snow avalanches, rockfalls, shallow landslides and volcanic activity represent a risk to mountain communities around the world. In particular, where documentary records about these processes are rare, decisions on risk management and landuse planning have to be based on a variety of other sources including vegetation, tree-ring data and natural hazard process models. We used a combination of these methods in order to evaluate dynamics of natural hazards with a focus on snow avalanches at Valle Las Trancas, in the Biobío region in Chile. Along this valley, natural hazards threaten not only the local human population, but also the numerous tourists attracted by outdoor recreational activities. Given the regional scarcity of documentary records, tree-ring methods were applied in order to reconstruct the local history of snow avalanches and debris flow events, which are the most important weather-related processes at respective tracks. A recent version of the model Rapid Mass MovementS (RAMMS), which includes influences of forest structure, was used to calculate different avalanche parameters such as runout distances and maximum pressures, taking into consideration the presence or absence of forest along the tracks as well as different modeled return periods. Our results show that local Nothofagus broadleaf forests contribute to a reduction of avalanche runout distances as well as impact pressure on present infrastructure, thus constituting a valuable ecosystem
\end{abstract}

disaster risk reduction measure that can substitute or complement other traditional measures such as snow sheds.

\section{Introduction}

In mountainous areas, settlements and infrastructure are commonly endangered by natural hazards such as snow avalanches, rockfalls, shallow landslides or volcanic activities. The documentation of past events of these natural hazards, including a detailed description of their properties (e.g., magnitude, affected area, type of damage) as well as their effects on and interactions with ecosystems, are important for assessing risk (Stoffel and Huggel, 2012; Gądek et al., 2017). In mountain ranges with a long history of settlement such as the European Alps, documentary records of gravitational natural hazards have been compiled for more than five centuries due to the frequent contact between mountain inhabitants and these phenomena (Laely, 1984). Yet, only more contemporary records have provided suitable information for accurate risk assessments (Wisner, 2004). In many other mountainous regions, human settlement has been rather limited until the 20th century and has substantially increased only during the last decades (Riebsame et al., 1996; Romero and Ordenes, 2004; Su et al., 2011). It is thus particularly important in more remote mountain areas, in which human populations 
and infrastructure are expanding, to learn more about (i) different natural hazard processes, (ii) how mountain ecosystems can be used to reduce risk and (iii) how people can be affected by these processes.

In regions where documentary records of past events of gravitational hazards are limited, dendrochronological methods provide a valuable and accurate tool for their spatiotemporal reconstruction (Braam et al., 1987; Shroder, 1980; Pop et al., 2016). The maximum length of this type of reconstruction depends primarily on the maximum age of the trees available for sampling at the study area. These ages, in turn, depend on two main factors: (i) the site history related to human interventions such as induced forest fires, logging and grazing (Mundo et al., 2013) and (ii) the frequency of events including avalanches and mass movements (i.e., more frequent events typically result in lower tree ages; Corominas and Moya, 2010). Documented damage produced by gravitational natural hazards (in particular snow avalanches) to old buildings, such as churches, has made it possible to couple long-term dendrochronological reconstructions with very precise information on partial and total destruction of infrastructure, thus validating the use of tree-ring methods for such studies (Fliri, 1998).

Forests can protect infrastructure from natural hazards in mountainous areas (Brang et al., 2006; Getzner et al., 2017). In the case of snow avalanches, which are main the focus of our investigation, mountain forests are known for stabilizing the snowpack in potential avalanche release areas and thus help to prevent avalanche initiation (Weir, 2002; Bebi et al., 2009,). Regarding small to medium-scale snow avalanches (i.e., <ca. $10000 \mathrm{~m}^{3}$ ), forests can also extract snow from the avalanche flow through deposition on the upslope-facing part of tree stems and on other obstacles (Feistl et al., 2014). Forest parameters such as stand composition, stem density and terrain roughness thus have not only an effect on stabilizing the snowpack in potential release areas (Bebi et al., 2009; Viglietti et al., 2010), but may also influence the spatial extent of small and medium-sized avalanches (Teich et al., 2012). However, snow avalanches can break, uproot and overturn trees (de Quervain, 1978; Takeuchi et al., 2011). Especially for large avalanches (i.e., $>10000 \mathrm{~m}^{3}$ ) that start far above the treeline, forests therefore have only a marginal influence on the kinetic energy and runout extent of avalanches (Bartelt and Stöckli, 2001). Nevertheless, mountain forests have thus been recognized as a cost-efficient but spatially and temporally varying protection Eco-DRR measure (Olschewski et al., 2012; Renaud et al., 2013).

Eco-DRR has been defined as "the sustainable management, conservation and restoration of ecosystems to reduce disaster risk, with the aim of achieving sustainable and resilience development" (Estrella and Saalismaa, 2013). Some of the most commonly applied measures to disaster risk reduction in Latin American countries are nature-based solutions such as protection forest, bio-engineering and ecoconstruction measures (McBreen, 2016). Nature-based solu- tions are particularly attractive due to their low costs, the use of local materials and their minimal impact on the landscape. A further advantage is that they have the potential to simultaneously reduce natural hazard risks and to provide benefits such as clean drinking water, increasing biodiversity, recreation, wood production and a wide range of other ecosystem services (Baró et al., 2015). In the Southern Andes, human settlement in villages and cities as we know them nowadays started only about 150 years ago, coinciding with one of the largest European immigration waves and the expansion of populations towards the slopes of the Andes (Germani, 1966). This process resulted in a sudden exposure of human populations and infrastructure to relatively well-known natural hazards but in a new environment. Since then and up to the present day, knowledge transfer has been made from (particularly) the European Alps to the Southern Andes to better understand the triggers and dynamics of natural hazards (Casteller et al., 2008; Stoffel et al., 2012). Yet, further major efforts are still needed to fulfill these goals.

Native forests in Chile provide several ecosystem services that directly or indirectly benefit human wellbeing, including the provision of food (e.g., Araucaria araucana seeds) and nontimber products, regulation of the water supply, carbon capture, conservation of soil, as well as the provision of habitat for biodiversity and space for recreation and tourism (Lara et al., 2003). These services also reduce the underlying vulnerabilities generated by the socioeconomic systems. The expansion of farming and forestry activities and the exploitation of hydropower resources have led to a fragmentation of ecosystems within the study area. Increasing urbanization associated with growing tourism in the area has expanded infrastructure and housing, putting more pressure on the local landscape and its biodiversity (Cordero et al., 2014) and increasing the exposure of people and infrastructure to snow avalanches and other natural hazards.

The overreaching goal of this investigation is to evaluate the role of mountain forest ecosystems as an Eco-DRR measure against natural hazards (primarily snow avalanches) at Valle Las Trancas, Nevados de Chillán, in the Biobío region of Chile. Within this region, avalanche-related casualties have been reported from the ski resort Nevados de Chillán and at the road connecting the village of Las Trancas with infrastructure located along the valley ending at the ski resort (La Discusión, 2011). Yet, the risk of snow avalanches in this area is largely unknown and, besides road temporal closures, no other passive or active measures (except within the limits of the ski resort Nevados de Chillán) are in place to reduce avalanche-related risks.

Besides snow avalanches, other natural hazard processes such as volcanic activity, rockfall, debris flows and shallow landslides also affect our study area. We thus complemented our detailed study on snow avalanche and vegetation interactions with investigations on other natural hazard processes that occur in the area. This allowed us to evaluate the importance of native forests in relation to different natural hazards 


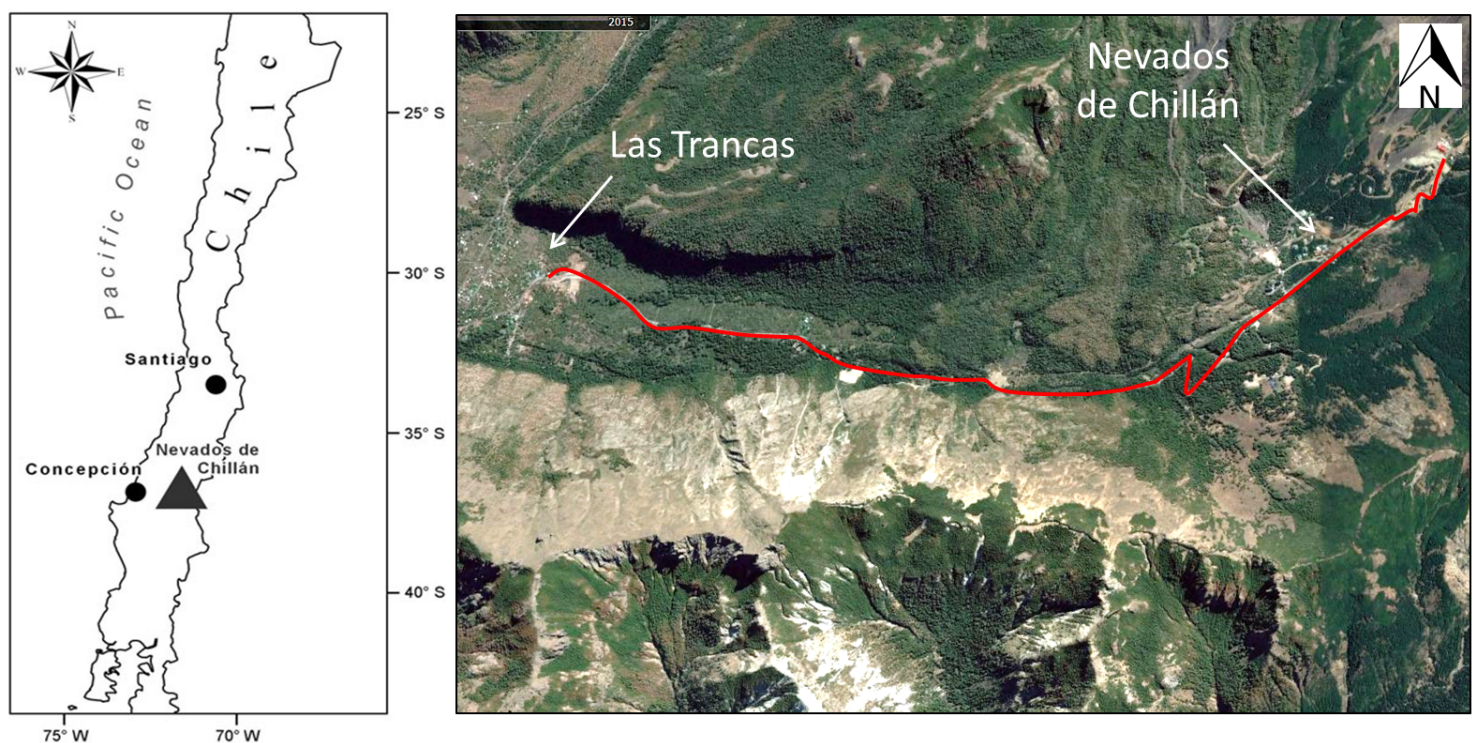

Figure 1. Study area. We focused our studies on natural hazards and protection forest along the road (red line) connecting Las Trancas with Nevados de Chillán. The north-facing slope adjacent to the road is much less vegetated compared to the south-facing slope, which is mostly explained by the lower radiation received on the latter and thus longer remaining snow cover that provides water in drier periods of the year (see also Fig. 2).

in the study area and to provide a suitable basis for proposing adequate Eco-DRR measures.

This study is part of the EPIC (Ecosystems Protecting Infrastructure and Communities) project, which has been implemented by the International Union for Conservation of Nature and several local partners and aims to demonstrate how improved ecosystem management can reduce the risk of disasters and help to adapt to climate change with different study cases around the world. The study is focused on answering the following questions. (i) What is the effect of avalanches and debris flows on the structure of affected forests? (ii) What is the influence of forest on avalanche runout and avalanche hazard? (iii) What assessment approach is most suitable to assess avalanche-forest interactions where information on past events is limited? (iv) What are the potential Eco-DRR measures for reducing overall risks in the study area?

\section{Material and methods}

\subsection{Study area}

The study area is located in the Biobío region of Chile in northern Patagonia. We focused our investigations at Valle Las Trancas, an east-west facing valley that is located within the limits of the transition zone of the biosphere reserve Corredor Biológico Nevados de Chillán - Laguna del Laja (Fig. 1). This biosphere reserve was opened by UNESCO on 29 June 2011. The presence of the northernmost population of the Patagonian huemul (Hippocamelus bisulcus), catego- rized as endangered by IUCN's (International Union for Conservation of Nature) red list of threatened species, and other rare species, as well as the high genetic diversity, are key issues that have made this biosphere reserve a high priority for conservation (San Martín, 2014).

In recent decades Valle Las Trancas has experienced high economic development due to its popular tourist attractions, mainly related to mountain sports and thermal springs (Pfanzelt et al., 2008). The municipality of Pinto, in which the Valle Las Trancas is located, lacks official land-use plans and regulations, leading to uncontrolled establishment of new buildings in the area. This development has also increased the demand of water for local consumption and of wood for heating.

A growing demand along Valle Las Trancas of new tourist infrastructure, in an area lacking appropriate hazard maps, can result in increased exposure to gravitational processes with serious risk for people. In addition, the ski resort Nevados de Chillán, located in the basin headwater, is one important local actor of the private sector authorized to cut patches of native forests to clear the land for new ski tracks. This potentially results in tradeoffs with the forests' provision of protection against snow avalanches.

\section{Biogeographic setting}

The investigated area is located between the temperate and Mediterranean macrobioclimates (Luebert and Pliscoff, 2006). It is characterized by dry summers and cold winters; more than $75 \%$ of the annual precipitation fall in winter be- 


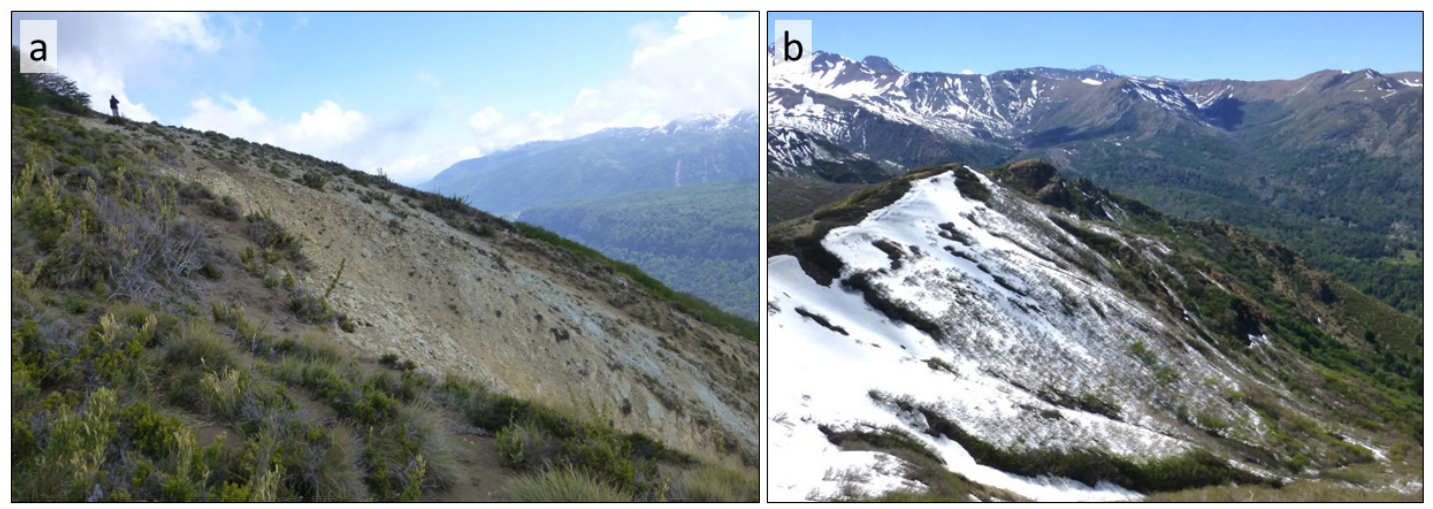

Figure 2. (a) Release area of avalanches, which in this particular track is also the initiation area of debris flows (df4; see Fig. 3 for reference). Just on the other side of the ridge (b; pictures taken the same day) we can observe a large amount of snow remaining from the previous winter.

tween April and September (Donoso, 1993). Local climate data obtained from a weather station located at Las Trancas $\left(36^{\circ} 54^{\prime} 41^{\prime \prime} \mathrm{S}, 71^{\circ} 28^{\prime} 44^{\prime \prime} \mathrm{W} ; 1251 \mathrm{~m}\right.$ a.s.1.), just at the entrance of the valley, report that the mean annual precipitation between 1998 and 2012 was $1007 \mathrm{~mm}$ (excluding the snow water equivalent). Mean annual temperature during the corresponding time period was $13.2^{\circ} \mathrm{C}$. Longer reliable climatic records, as well as specific data on snow heights, rainfall intensities and extreme snowfall events, are unavailable for the study area.

A high diversity of geological substrates caused by high volcanic activity characterizes the study region. Adjacent to the study area is the Nevados de Chillán volcano, which consists of the Cerro Blanco and Las Termas subcomplex (formed about 40000 years ago). The most recent eruptions from the Nevados de Chillán volcano occurred in the years 1973, 2003 and 2016; due to the presence of tourist facilities, it is categorized as one of the volcanos with the highest damage potential in Chile (Dixon et al., 1999). These diverse geological substrates are overlaid with characteristic soils classified as Inceptisols, which develop from these volcanic products (Freiberg, 1984; Soil Survey Staff, 2014). The high diversity of geological substrates leads in turn to 11 different vegetation units (Pflanzelt et al., 2008). Close to the riverbed in humid localities, Nothofagus dombeyi (Mirb.) Oerst. forests can be found. The other parts of the forest are mixed forest stands of Nothofagus dombeyi, Nothofagus pumilio (Poepp. \& Endl.) Krasser and Nothofagus obliqua (Mirb.) Oerst. In sections of the study area, Chusquea culeou and coirones can be found, dominated by the species Chusquea culeou (E. Desvaux). On the upper portion of the slopes near the ridges, Nothofagus pumillio krummholz-type vegetation adds to the forest diversity.

\subsection{Remote-sensing analyses}

Identification of gravitational natural hazards within the study area was conducted in an early stage of this investigation and complemented with subsequently obtained geographical information. We first focused on spatially demarcating the avalanche tracks that reached (according to available records) infrastructure along the road of Valle Las Trancas. Spatial analysis and interpretation of aerial images were made using ArcMap 10.2 (ESRI, 2013). Google Earth images were used to display the information and acted as a basis for the interpretation of aerial images. Additionally, available aerial images of the study area (from the years 1978, 1979, 1982, 1998 and 2000) were stereoscopically analyzed in order to identify chronological modifications in the forest structure due to natural disturbances following the approaches of Bebi et al. (2001) and Panayotov et al. (2011). For the assessment of the current forest structure in selected avalanche tracks, we complemented these analyses with high-resolution remote-sensing data (including a digital terrain model (DTM) and cover image) obtained in February 2015 with an eBee drone (resolution: $8 \mathrm{~cm} \mathrm{pixel}^{-1}$ ).

We complemented these data with repeated field surveys. Trees that were either sampled or simply identified for features of interest were individually positioned using a portable navigation system (model: GPSMAP ${ }^{\circledR}$ 64s). Forests in which the spatial extent of past avalanches was visible in the field were mapped using the same method, in particular with borders and avalanche runouts. Photographs were taken of avalanche release zones (which are mostly above the treeline and on steep slopes) from different angles and locations (Fig. 2). These photographs subsequently helped for spatial demarcation of these release zones using a Geographic Information System (GIS).

Between the village of Las Trancas and the base of the ski resort Nevados de Chillán ( $36^{\circ} 54^{\prime} 12^{\prime \prime} \mathrm{S}, 71^{\circ} 24^{\prime} 32^{\prime \prime} \mathrm{W}$; i.e., 


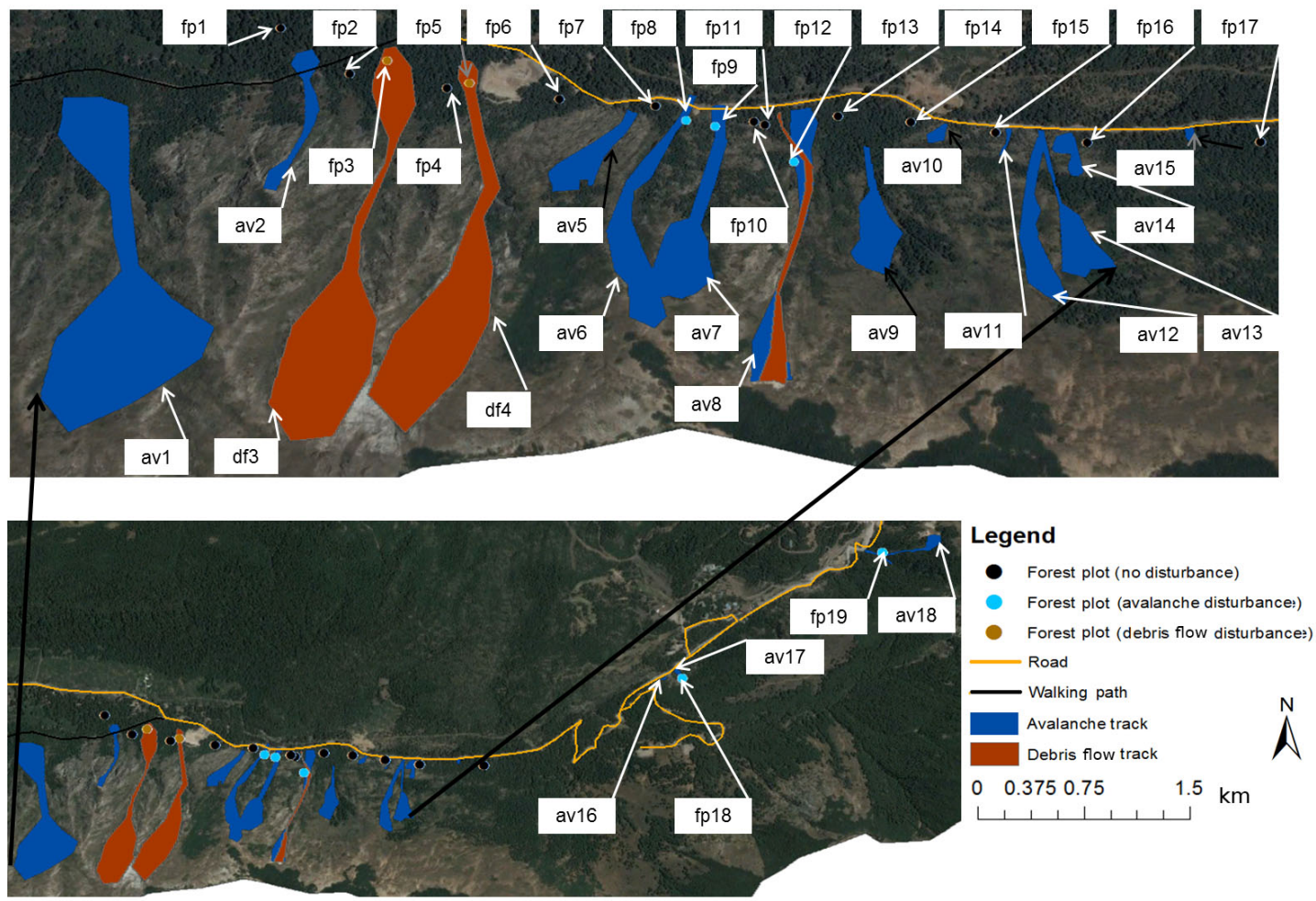

Figure 3. Snow avalanche tracks, debris flow tracks and forest plots (fp) at the study area. Tracks depicted in blue correspond to snow avalanches, whereas those in red correspond to both snow avalanches and debris flows. A total of 18 tracks were identified in the study area and 19 forest plots were defined.

end of the road) we were able to identify 18 active (i.e., with at least one documented event) avalanche tracks (Fig. 3).

\subsection{Forest structural analyses}

Two different approaches were applied to reconstruct a spatiotemporal occurrence of gravitational natural hazards. The first approach aimed to evaluate the forest age and structure in specific plots. The locations of these forest plots were selected according to the following criteria: (i) plots are placed at each natural hazard patch (i.e., avalanche/debris flow track) with the presence of forest; and (ii) at each forest stand was in between two natural hazard patches. Each plot had a radius of $10 \mathrm{~m}$, thus covering a surface of $314 \mathrm{~m}^{2}$. Parameters registered at the forest plots included terrain roughness, canopy density, properties of the shrub layer and slope angle. For each tree within the plots with a diameter at breast height $(\mathrm{DBH})$ larger than $8 \mathrm{~cm}$, further parameters were recorded: species, diameter, height and social status. Additionally, at least five randomly selected trees were cored at each plot to estimate the ages of the stands. The gathered data from the forest structure plots were analyzed using the statistic software R (R Core Team, 2014).

\subsection{Tree-ring analyses}

The second approach focused on identifying particular trees at selected avalanche tracks with the largest amount of visible damage (which is typically associated with repeated events), such as broken stems and/or branches, decapitation, uprooting and exposed scars. From the total of 18 avalanche tracks identified, we applied this approach (hereafter called "selective sampling") to two of them (defined as av6 and av9; Table 1). We selected these two tracks for the following reasons: av6 had one recorded avalanche event in 2011 (which reportedly caused one casualty) that could be used for calibration purposes, whereas av9 presented a very clear avalanche runout zone and borders with numerous trees evidencing recent events. Selected trees were sampled using increment borers (Haglöfs; width $0.5 \mathrm{~cm}$ ) as well as handsaws, and in all cases unnecessary damage to living trees was avoided in this protection forest (Bebi et al., 2001; Dorren et al., 2004). Morphological features of sampled trees, such as the height of the damage along the main stem, size of the scars and inclination of the stems were registered and complemented by drawings and pictures.

All tree-ring samples were prepared following standard dendrochronological techniques (Stokes and Smiley, 1968) and subsequently ring-width measured using a LINTAB sys- 
Table 1. Samples collected at different tracks and forest plots.

\begin{tabular}{llrr}
\hline Code & Sector & $\begin{array}{r}\text { Cores } \\
(n)\end{array}$ & $\begin{array}{r}\text { Cross } \\
\text { sections }(n)\end{array}$ \\
\hline av6 & avalanche track \& runout & 121 & 5 \\
av9 & avalanche track \& runout & 73 & 9 \\
fp1 & unaffected forest & 6 & 0 \\
fp2 & unaffected forest & 5 & 0 \\
fp3 & debris flow runout & 5 & 0 \\
fp4 & unaffected forest & 5 & 0 \\
fp5 & debris flow runout & 6 & 0 \\
fp6 & unaffected forest & 5 & 0 \\
fp7 & unaffected forest & 5 & 0 \\
fp8 & avalanche runout & 5 & 0 \\
fp9 & avalanche runout & 5 & 0 \\
fp10 & unaffected forest & 6 & 0 \\
fp11 & unaffected forest & 5 & 0 \\
fp12 & avalanche runout & 4 & 0 \\
fp13 & unaffected forest & 5 & 0 \\
fp14 & unaffected forest & 5 & 0 \\
fp15 & unaffected forest & 6 & 0 \\
fp16 & unaffected forest & 5 & 0 \\
fp17 & unaffected forest & 6 & 0 \\
fp18 & avalanche runout & 6 & 0 \\
fp19 & avalanche runout & 5 & 0 \\
\hline
\end{tabular}

tem from RINNTECH, Germany. The software COFECHA was utilized to detect (and if necessary to correct) dating errors, using chronological tree samples from adjacent undisturbed sectors of the forest as a reference (Holmes, 1983). Further, every tree-ring sample was carefully examined for the presence of scars, growth releases and growth decreases, as well as peculiar features in the wood such as frozen rings or wood compartmentalization. Growth reactions were grouped into three different categories following Dubé et al. (2004). Both the expert (Stoffel and Corona, 2014) and indices (Shroder, 1978) approaches were then applied in a comparative way to achieve a final reconstruction of events at each avalanche/debris flow track.

In regions where the precipitation patterns determine the occurrence of debris flows during the vegetation period of trees, it is possible to differentiate between the occurrence of snow avalanches and debris flows by identifying the position of the injuries within the tree rings (i.e., dormancy for avalanches and active growth for debris flows; Stoffel et al., 2012). In our study area, where most precipitation occurs in winter, we could determine that most of the studied debris flows occurred in spring due to rain-on-snow events.

\subsection{Snow avalanche simulations}

Numerical simulation models have been used to reconstruct snow avalanches in various mountain regions including the Andes (Valero et al., 2016), central Europe (Blahut et al., 2017), Japan (Takeuchi et al., 2011) and
Scandinavia (Gauer and Kristensen, 2016). The software RAMMS was used to conduct snow avalanche simulations at Valle Las Trancas. RAMMS is a two-dimensional software to calculate mass movement dynamics in a threedimensional terrain (Christen et al., 2010). We applied RAMMS::AVALANCHE version 1.6.25@ (from WSL-SLF) with its new forest applications. Compared to standard simulations with RAMMS::AVALANCHE, this version differentiates among the effects of different forest structural characteristics on avalanche runout. Therefore, spatial information on crown coverage, roughness and DBH had to be defined from the forest plot survey and remote-sensing data for the simulations at each track. Based on the forest type, crown coverage and roughness in the area, we subsequently deduced explicit spatial information on the detrainment coefficient $K\left[\mathrm{~kg} \mathrm{~m}^{-1} \mathrm{~s}^{-2}\right]$, which represents the breaking power that a forest exerts on the avalanche flow (Feistl et al., 2015). Information regarding snow height and snow density along the track and at the release areas was not available for each avalanche event. Thus they could not be considered in our simulations and had to be estimated based on typical and extreme snow situations for this region. As the exact locations and sizes of avalanche releases were also not available for all events, we conducted GIS analyses using topographic parameters (e.g., slope, aspect, confinement and distance to the next ridge) in order to best estimate this information (Maggioni and Gruber, 2003; Bühler et al., 2013). Simulations with both ca. 10 and ca. 100-year return periods were conducted. For extreme scenarios with ca. 100-year return periods, we also considered the largest possible release areas based on topographical settings in and around potential release areas. Avalanche friction values were differentiated between open, channeled and gully slopes and also for different forest structural characteristics following the approach and protocol of Feistl et al. $(2015,2016)$.

At avalanche tracks 6 and 9 (av6 and av9), specific information regarding runout distances from past events was available (both from tree-ring data and documentary records). Out of the results of our tree-ring analyses, trees with synchronous reactions to avalanches at these run-out zones were used to delineate the affected area of past (treering dated) events. We then compared this information with the spatial data provided by the numerical simulations with RAMMS. To further evaluate the effect of local forests on avalanche dynamics, different simulations considering both the presence and absence of forest were conducted. Further, avalanche simulations were conducted at a selected track (av6) in order to quantify the improved protective capacity of the forest by conducting additional afforestation, with the assumption that the additionally considered forests have similar functional properties to the current forest. 


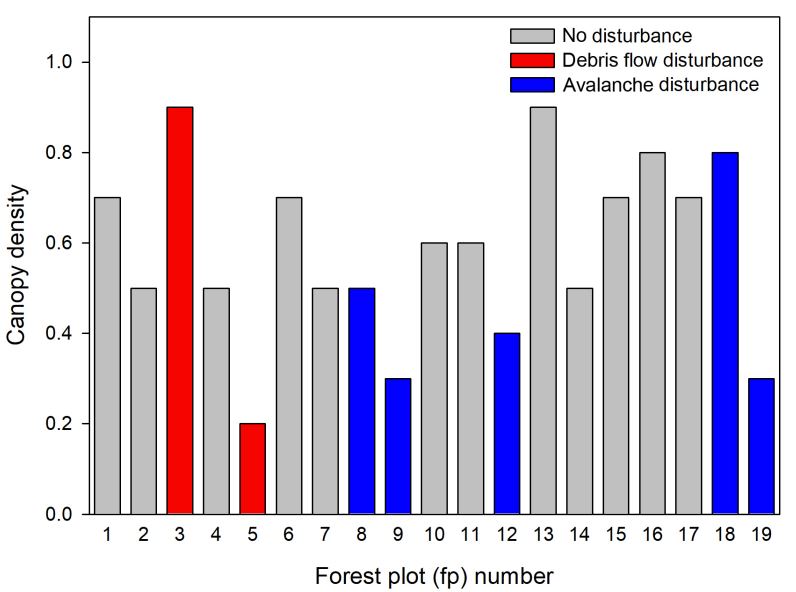

Figure 4. Canopy density distribution (\%) per plot.

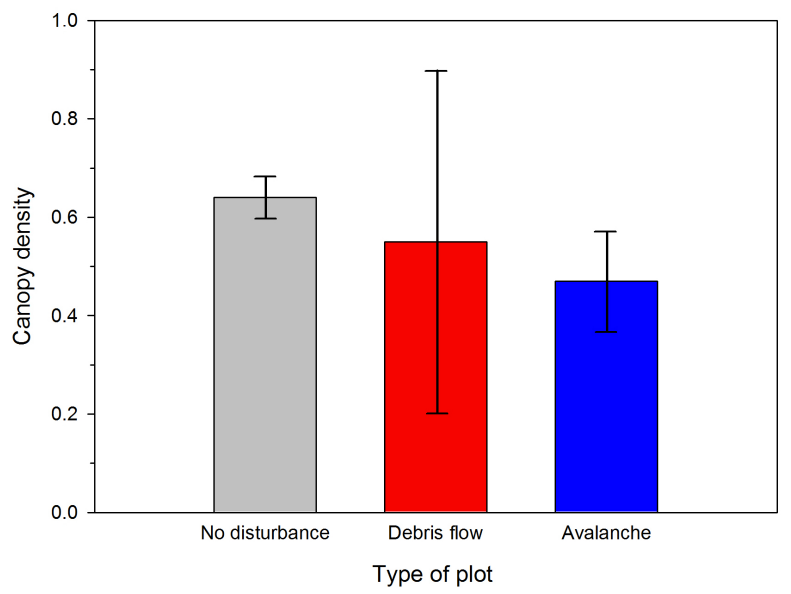

Figure 5. Canopy density distribution (\%) per disturbance.

\section{Results}

\subsection{Forest structure in disturbed and control plots}

Our analyses show that avalanches and debris flows play a role in influencing the structure of the forest at the study area. Canopy densities of the investigated plots range between 20 and $90 \%$ (average value of $60 \%$; Fig. 4). By grouping plots in different categories (i.e., no disturbance, debris flows and snow avalanches), we observe that avalanches reduce the canopy density by about $20 \%$ in relation to undisturbed forest, whereas for debris flow this reduction is $10 \%$ (Fig. 5); these results are, however, not significant ( $p$ value $>0.05$ ).

\subsection{Reconstruction of events based on tree-ring analyses}

The results of our tree-ring analyses allowed us to reconstruct past snow avalanche and debris flows years at the investigated tracks. Scars and abrupt growth changes provided the

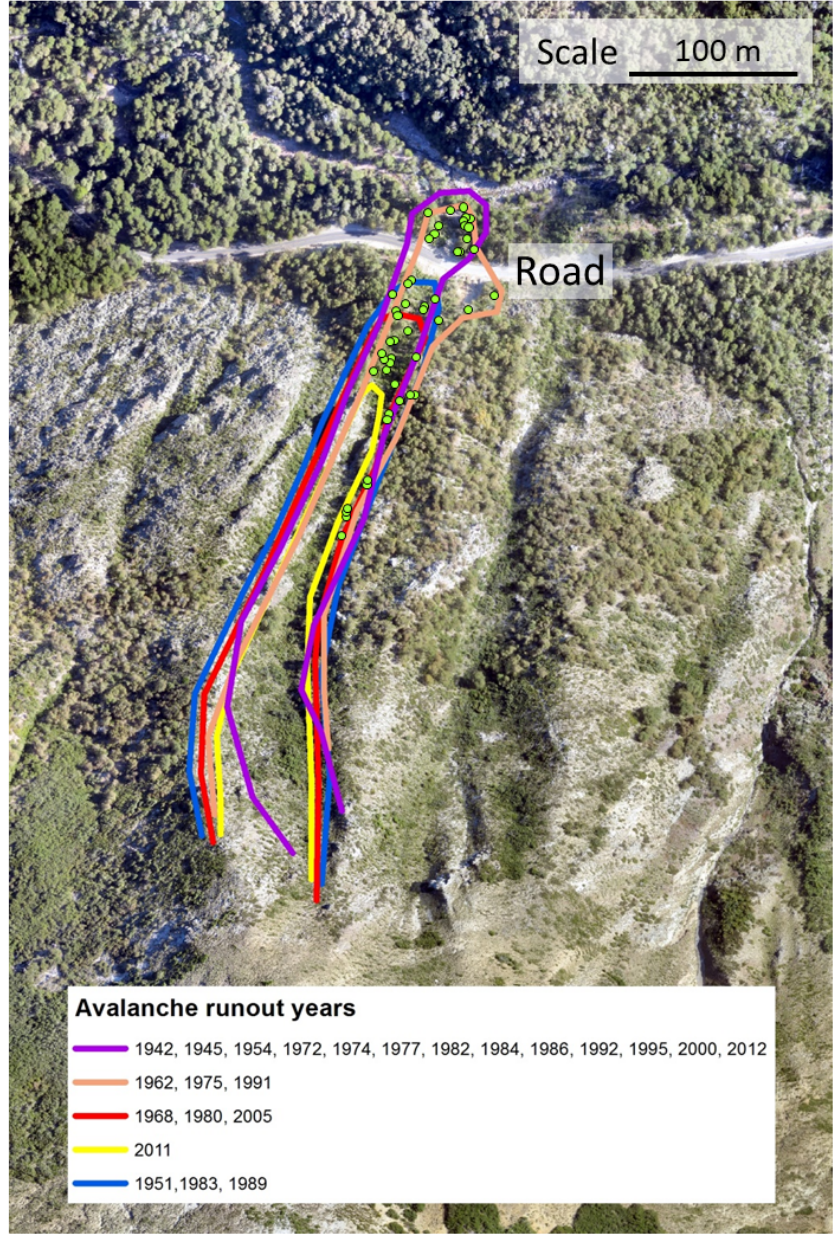

Figure 6. Reconstructed borders and runouts at avalanche track 6 using tree-ring data from the first registered event in 1942 up to the sampling time in 2015. The green circles indicate sampled trees.

most reliable indicators of past events. Table 2 contains a list of all years during which, according to our reconstruction, either snow avalanches or debris flows occurred at the investigated tracks. Only forest plots located in avalanche or debris flows patches are considered here (see Fig. 3 for reference), in addition to tracks av6 and av9 in which the selective sampling was conducted.

The first year during which an avalanche event was detected in our tree-ring data is 1942 . The main factors that prevent the extension of our reconstruction beyond that year are, on the one hand, the young age of the local forests and, on the other hand, wood decay. At avalanche track 6 (av6; using selective sampling), a forest plot (fp8) was also selected in order to compare the event reconstruction using both approaches. We observed that only two events have been captured at fp8 since 1942, whereas the selective sampling allowed a reconstruction of 23 events (Table 2). During 1995 and 2000 a particularly high occurrence of events was registered at many of the investigated tracks. 
Table 2. Reconstructed avalanche and debris flow events at the investigation area. Fp3 and fp5 show event years in the debris flow tracks (df3 and df4), whereas fp8, av6, fp9, fp12, av9, fp18 and fp19 show event years at different avalanche tracks (av6, av6, av7, av8, av9, av17 and av18).

\begin{tabular}{|c|c|c|c|c|c|c|c|c|c|}
\hline $\begin{array}{l}\text { Avalanche/ } \\
\text { debris flow } \\
\text { years }\end{array}$ & $\begin{array}{c}\text { fp3 } \\
\text { (df3) }\end{array}$ & $\begin{array}{c}\mathrm{fp} 5 \\
\text { (df4) }\end{array}$ & $\begin{array}{c}\text { fp8 } \\
(\operatorname{av6})\end{array}$ & av6 & $\begin{array}{c}\text { fp9 } \\
(\text { av7) }\end{array}$ & $\begin{array}{l}\text { fp12 } \\
\text { (av8) }\end{array}$ & av9 & $\begin{array}{c}\text { fp18 } \\
\text { (av17) }\end{array}$ & $\begin{array}{c}\text { fp19 } \\
\text { (av18) }\end{array}$ \\
\hline 2014 & & $\mathrm{x}$ & & & & & & & \\
\hline 2012 & & & & $\mathrm{x}$ & & & $\mathrm{x}$ & & \\
\hline 2011 & & & & $\mathrm{x}$ & & & $\mathrm{x}$ & & \\
\hline 2010 & $\mathrm{x}$ & & & & & & $\mathrm{x}$ & & \\
\hline 2005 & & & & $\mathrm{x}$ & & & & $\mathrm{x}$ & \\
\hline 2002 & & & & & & & $\mathrm{x}$ & & \\
\hline 2000 & & & & $\mathrm{x}$ & & $\mathrm{x}$ & $\mathrm{x}$ & $\mathrm{x}$ & \\
\hline 1995 & $\mathrm{x}$ & $\mathrm{x}$ & $\mathrm{x}$ & $\mathrm{x}$ & $\mathrm{x}$ & $\mathrm{x}$ & $\mathrm{x}$ & & \\
\hline 1992 & & & & $\mathrm{x}$ & & & & & \\
\hline 1991 & & & & $\mathrm{x}$ & & $\mathrm{x}$ & $\mathrm{x}$ & & \\
\hline 1989 & & & & $\mathrm{x}$ & & & & $\mathrm{x}$ & $\mathrm{x}$ \\
\hline 1986 & & & $\mathrm{x}$ & $\mathrm{x}$ & & & & $\mathrm{x}$ & \\
\hline 1984 & & & & $\mathrm{x}$ & & & & & \\
\hline 1983 & & & & $\mathrm{x}$ & & & $\mathrm{x}$ & & $\mathrm{x}$ \\
\hline 1982 & & & & $\mathrm{x}$ & & & & & \\
\hline 1980 & & & & $\mathrm{x}$ & & & & & \\
\hline 1977 & & & & $\mathrm{x}$ & & & & & \\
\hline 1975 & & & & $\mathrm{x}$ & & & & & \\
\hline 1974 & & & & $\mathrm{x}$ & & & & & \\
\hline 1972 & & & & $\mathrm{x}$ & & & & & \\
\hline 1968 & & & & $\mathrm{x}$ & & & & & \\
\hline 1964 & & & & & $\mathrm{x}$ & & & & \\
\hline 1962 & & & & $\mathrm{x}$ & & & & & \\
\hline 1961 & $\mathrm{x}$ & & & & & & & & \\
\hline 1957 & $\mathrm{x}$ & & & & & & & & \\
\hline 1954 & & & & $\mathrm{x}$ & & & & & \\
\hline 1951 & $\mathrm{x}$ & & & $\mathrm{x}$ & & & & & \\
\hline 1947 & $\mathrm{x}$ & & & & & & & & \\
\hline 1945 & & & & $\mathrm{x}$ & & & & & \\
\hline 1942 & & & & $\mathrm{x}$ & & & & & \\
\hline
\end{tabular}

By making a linkage between trees showing synchronic avalanche reactions we can reconstruct five different runouts at av6, and four of them correspond to more than one year (Fig. 6). Events with a shorter runout compared to the runout of 2011 could not be reconstructed due to the absence of trees.

\subsection{Influence of forest on avalanche dynamics}

In order to evaluate the influence of the Nothofagusdominated forests on avalanche dynamics (and thus quantify its protective capacity), avalanche simulations considering both the presence (in its actual situation) and absence of forest were conducted. Simulations for avalanche track 9 (av9) are shown here as an example. This track is largely forested in its runout zone, providing a potentially important protective function for the road crossing the valley. Our simulations show that for a 10-year return period scenario without considering forests, the spatial extent of avalanches is $19 \%$ larger compared to avalanches running in a forested track. The runout of the avalanche in this nonforested scenario thus reaches the road, in contrast to the runout of the forested scenario, which does not reach the road or other infrastructure (Fig. 7). Considering a 100 -year return period scenario for the same track, the absence of forest would determine that avalanches could reach the road, their spatial extent being $23 \%$ larger than with forests along the track (Fig. 8).

Simulations of avalanches considering artificial afforestation scenarios were conducted for av6, which shows the largest potential impact on infrastructure along the road (see also Fig. 6), considering a 10-year return period scenario. Our results show that the runout of avalanches would not be significantly shortened (5\%) due to afforestation at the track, but that there would be a reduction in maximum avalanche pressure at the intersection with the road of $24 \%$ (Fig. 9). 


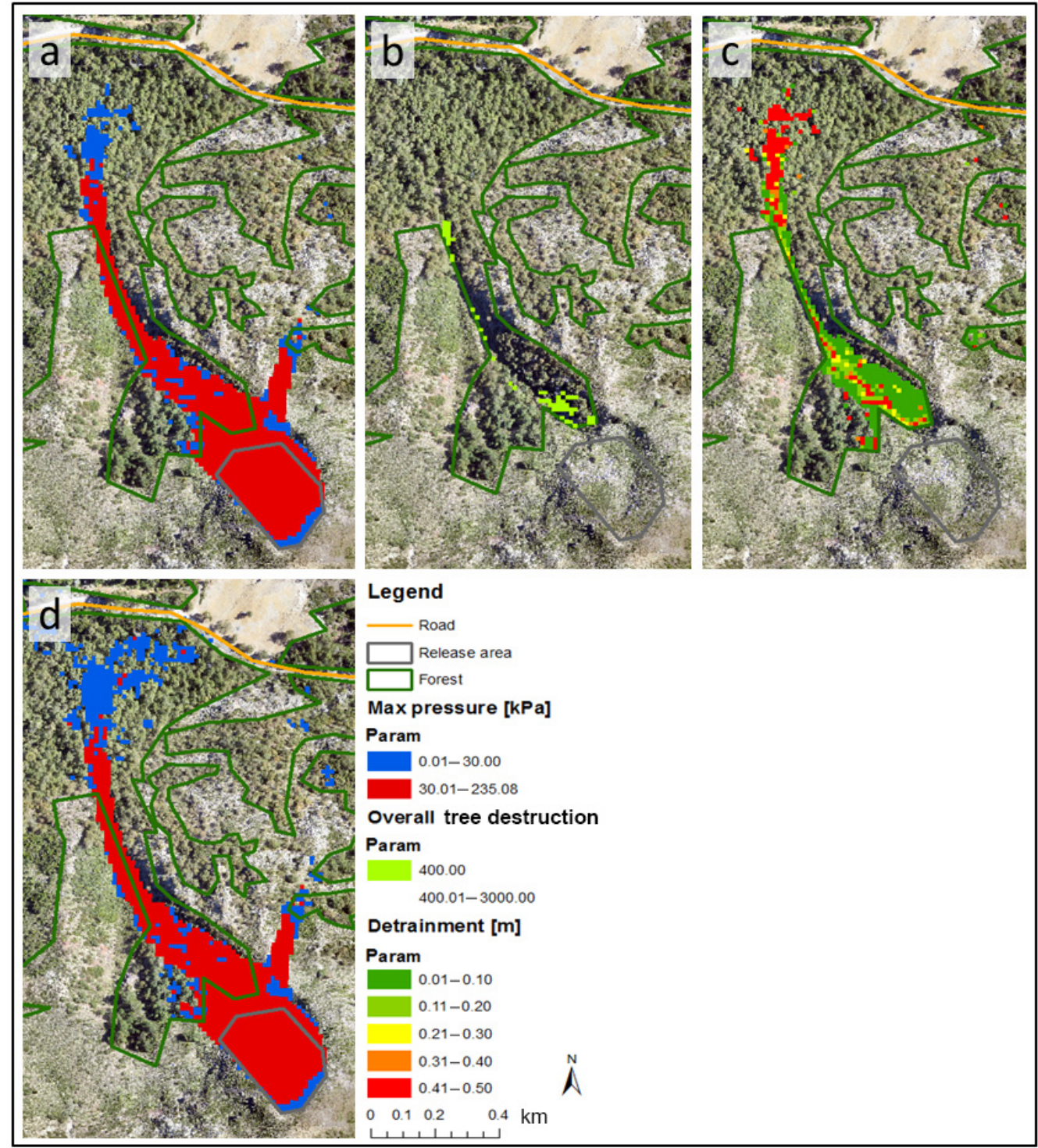

Figure 7. Avalanche simulations at avalanche track 9 with a 10-year return period: (a) maximum pressure of an avalanche scenario with forest, (b) area where forest is destroyed, (c) detrainment in the forest and (d) the maximum pressure of an avalanche scenario without considering forests.

\section{Discussion}

Snow avalanches and debris flows are natural hazards that have not been thoroughly studied in Chile (Espinosa et al., 1983). In this investigation we identified the main natural hazards representing a risk to local communities at Valle Las Trancas within the biosphere reserve Nevados de Chillán Laguna del Laja. Besides the continuous growth of its human population, the valley receives a large and increasingly growing number of visitors attracted by leisure activities and the magnificent mountain landscape throughout the year. Yet, the lack of land-use planning and regulation on natural hazards such as snow avalanches and debris flows contribute to risk to people and infrastructure. This study assessed the role of native mountain forests, represented here by different species of Nothofagus, in applying an Eco-DRR approach in order to reduce hazard exposure. It is assumed that native mountain forests could be further conserved and sustainably managed to improve their protective capacity against natural hazards such as avalanches or debris flows and thus reduce the risk of disasters in the area.

The lack of documentary records of spatiotemporal patterns of gravitational natural hazards in the Southern Andes is a recognized limitation to estimating related risks. Efforts have been made in the past to apply tree-ring methods to this region in order to substitute for or complement documen- 


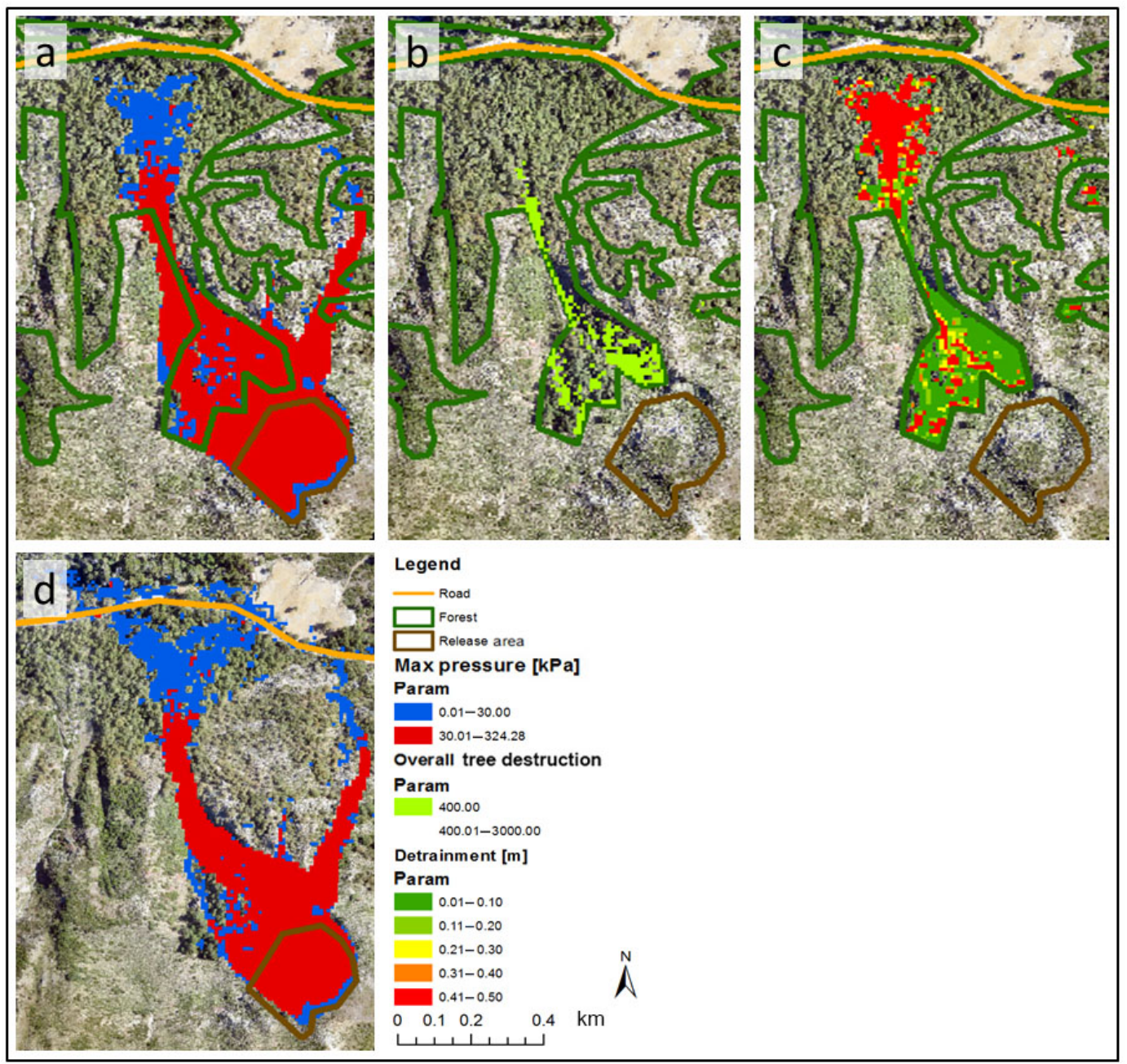

Figure 8. Avalanche simulations at avalanche track 9 with a 100-year return period: (a) maximum pressure of an avalanche scenario with forest, (b) area where forest is destroyed, (c) detrainment in the forest and (d) the maximum pressure of an avalanche scenario without considering forests.

tary records, which, even if available, tend to be fragmentary (e.g., Mundo et al., 2007; Casteller et al., 2009, 2011, 2015). Methodological limitations exist, however: for example, a reconstructed avalanche event year implies the occurrence of at least one event during that particular winter, but it is not possible to determine whether more than one event occurred at the same track during the same winter. In contrast, distinguishing among events occurring in different times of the year is possible by identifying the position of reaction wood within tree rings. In regions where debris flows occur in summer, it is normally possible to distinguish their associated tree-ring reactions (from early wood to late wood) from those originating from snow avalanche impacts (the reaction can be found in this case at the boundary of two rings; Stoffel et al., 2006). In our study area, we were able to distinguish between avalanche and debris flow events using treering methods as snow avalanches occur in winter and debris flows, in turn, typically occur during the early spring when rain events melt the snow from the winter remaining on the catchments. In addition, available records, types of damage in the forest, topographical features (including channel geometry) and process modeling helped us to distinguish one process from another.

As we have shown, different sampling techniques can lead to different results when analyzing temporal patterns of snow avalanches and debris flows. The selection of single trees with widespread visible damage from past events at the borders (and for snow avalanches also at the runouts) of the tracks can provide longer event reconstructions compared to sampling in plots adjacent to disturbed areas. Yet, sampling plots, as we have shown, can also provide valuable data related to forest structure, from which it is possible to infer past event dates. In addition, forest plots are a valuable source of information and can be analyzed with remote-sensing tools 


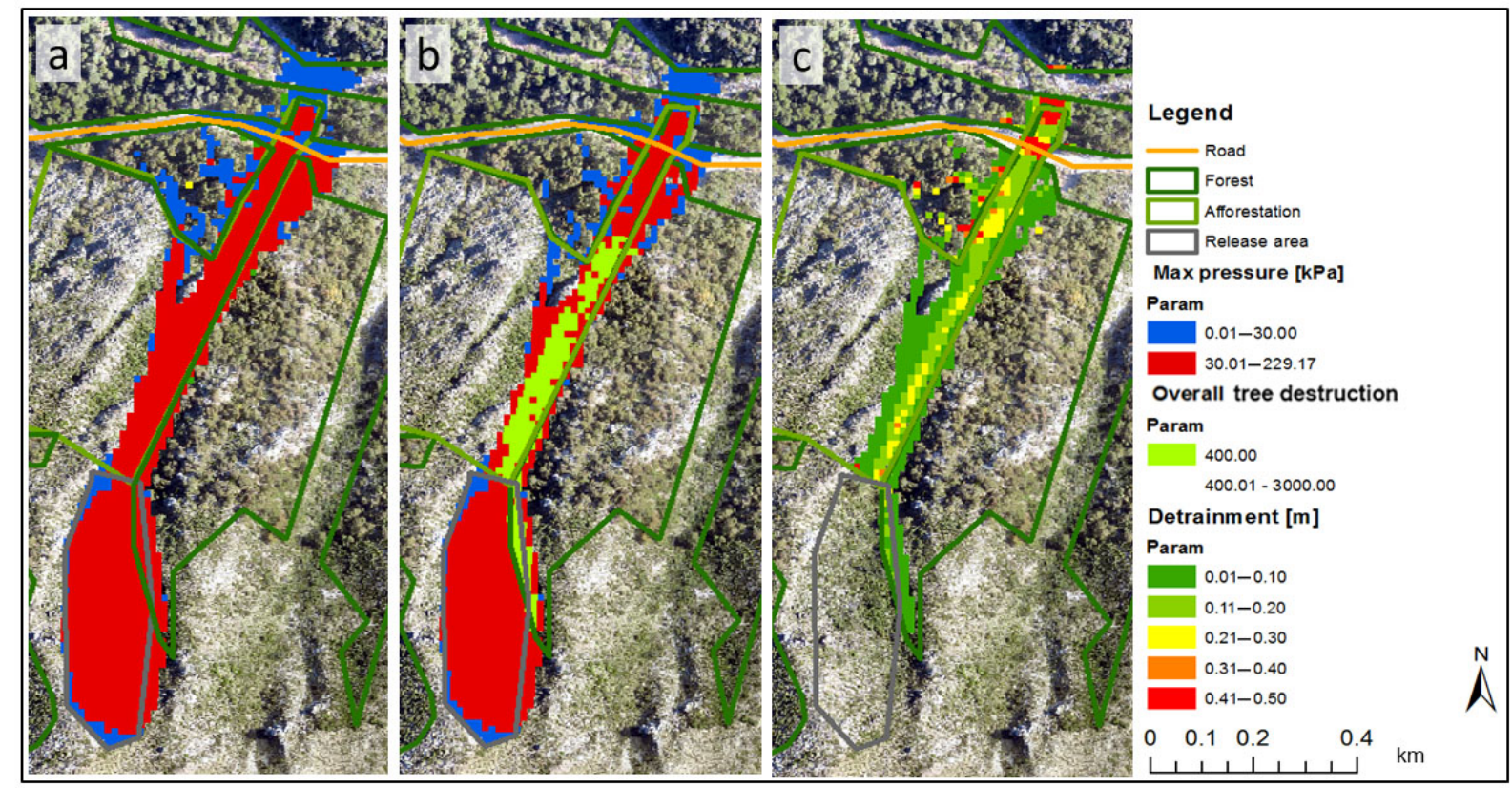

Figure 9. Influence of additional afforestation in avalanche track 6 with a 10-year return period: (a) maximum pressure in an avalanche simulation without additional forests, (b) maximum pressure and overall tree destruction in an avalanche simulation with additional forest and (c) detrainment in an avalanche simulation with additional forest.

and for larger areas. A combination of both sampling approaches was found to be the most useful.

The role of mountain forests as protective measures against natural hazards has been acknowledged for centuries in the European Alps, where mountain settlements are in close contact with phenomena such as snow avalanches and landslides (Price and Thompson, 1997; Getzner et al., 2017. The use of the new model RAMMS::AVALANCHE (which considers forest effects), developed and first tested in the Alps, was used in this investigation to reconstruct past avalanche events and to determine potential avalanche scenarios. These simulations, with a few exceptions (Casteller et al., 2008), are practically nonexistent in the Andes. This type of multi-methodological approach has proven to be most effective (Gądek et al, 2017), in particular in regions where documentary data on past events is scarce. In addition to the methods and data used in this study, the availability of detailed data, e.g., on the size and precise location of avalanche release zones (including snow depth), types of snow and snow entrainment along the track would allow even more robust event modeling.

Our results indicate that local native broadleaf forests may influence avalanche dynamics, particularly in small to medium-sized events if the distance between the release area of the avalanche and the upper timberline is less than ca. $200 \mathrm{~m}$ (Weir, 2002; Teich et al., 2012). The effect of broadleaf forests on avalanche releases is certainly less than that of evergreen forests due to lower interception rates during snowfall (Lundberg et al., 2004; Bebi et al., 2009). How- ever, their effect on reducing runout distances may still be considerable, in particular for small avalanches that do not cause widespread tree breakage (Feistl et al., 2014). In such cases, a shortening of runout distances and reduction of impact pressure can largely be explained by the extraction of snow mass from the avalanche volume and thus the reduction of the momentum of the avalanche flow by the trees. These results suggest that appropriate and spatially well-targeted afforestation may potentially reduce risks related to snow avalanches in our study area. In contrast to grey measures such as snow sheds (Campbell et al., 2007), afforestation would clearly have a less detrimental effects on the provision of other ecosystem services, in particular if they are conducted with regional tree species and locally limited to appropriate site conditions (Schönenberger, 2001). In line with the expectations of the local community (Cortés Donoso, 2017), strict controls of further forest cutting within the biosphere reserve are needed in order to allow sustainable protection against natural hazards without major impacts on the forest structure and ecosystem dynamics (Bebi et al., 2017).

As indicated by gathered data at the study site (Cortés Donoso, 2017), the two most relevant risks for the local community at Valle Las Trancas are snow avalanches and volcanic activity. The large volcanic complex has recently reached over 18 months of visible activity. In addition, the occurrence of forest fires in Chile has increased exponentially during recent years, representing a major national hazard (González et al., 2011). While the potential effects of Eco-DRR measures against volcano activity are very limited, 
they represent a window of opportunity in terms of protection against snow avalanches. The promotion of services provided by the native forest and the participation of the local community in conserving and sustainably managing the forest are issues to be closely considered.

\section{Conclusions}

Our results show that both avalanches and debris flows can affect the structure of Nothofagus forests by reducing canopy density. This information, together with tree-ring indicators such as scars and abrupt growth changes, allows the determination of spatiotemporal patterns of past events. In turn, Nothofagus forests may influence avalanche dynamics, particularly in small to medium-sized events if the distance between the release area of the avalanche and the upper timberline is less than ca. $200 \mathrm{~m}$. A combination of different methods and approaches is crucial to a comprehensive understanding of interactions between natural hazards and forest ecosystems. This is particularly true for complex mountainous regions like the Nevados de Chillán, where in many cases natural hazards interact with each other, where the complex topography (steep mountain terrain) results in a more difficult acquisition of accurate digital terrain models (which are necessary for the applied simulation models) and in particular where historical records on natural hazard regimes are scarce. Overall, the findings of our study suggest that the conservation of regional native forests may contribute, at least in specific parts of the region, as an Eco-DRR measure for protecting against natural hazards. Given the relevance of snow avalanches and other gravitational natural hazards for the local community and for tourism, it is important to better integrate spatial information related to these processes as input for land-use planning tools along the Valle Las Trancas. This data integration can complement pre-existing volcanic hazard maps to prevent human casualties and damage to infrastructure.

Data availability. Our research data will be uploaded in the coming weeks to the new data portal Envrionmental Data Portal EnviDat (ENVIDAT https://www.envidat.ch/).

Competing interests. The authors declare that they have no conflict of interest.

Acknowledgements. The authors thank the Ministry of Environment of Chile (MMA) for its political support throughout the implementation of the project and the International Climate Initiative (ICI) of the German Federal Ministry for Environment, Nature Conservation, Building and Nuclear Safety (BMUB) for funding the project. Gabriela Jara Aburto and Gabriel Orozco from SERNAGEOMIN are acknowledged for providing support and valuable information from the beginning to the end of the project. Field assistants Ernesto Corvalán, Jorge Silva, Eugenia Marcotti, Carolina Córdova, Viola Debus, Álvaro Gutiérrez and Paul Szejner permitted field activities to be successfully conducted. Likewise, our gratitude goes to Jaime Soto and Leandro Olivares, who conducted drone flights at the study area and shared this information with us for the avalanche modeling. Last but not least, we thank Marc Christen, Yves Buehler and Lukas Stoffel at the SLF Institute for their valuable insight related to the avalanche modeling.

Edited by: Thom Bogaard

Reviewed by: two anonymous referees

\section{References}

Baró, F., Bugter, R., Gómez-Baggethun, E., Hauck, J., Kopperoinen, L., Liquete, C., and Potschin, P.: Green Infrastructure, in: OpenNESS Ecosystem Service Reference Book, edited by: Potschin, M. and Jax, K., EC FP7 Grant, Agreement no. 308428, available at: www.openness-project.eu/library/ reference-book (last access: 13 April 2018), 2015.

Bartelt, P. and Stöckli, V.: The influence of tree and branch fracture, overturning and debris entrainment on snow avalanche flow, Ann. Glaciol., 32, 209-216, 2001.

Bebi, P., Kienast, F., and Schönenberger, W.: Assessing structures in mountain forests as a basis for investigating the forests' dynamics and protective function, For. Ecol. Manage., 145, 3-14, 2001.

Bebi, P., Kulakowski, D., and Rixen, C.: Snow avalanche disturbances in forest ecosystems - State of research and implications for management, For. Ecol. Manage., 257, 1883-1892, 2009.

Bebi, P., Seidl, R., Motta, R., Fuhr, M., Firm, D., Krumm, F., Conedera, M., Ginzler, C., Wohlgemuth, T., and Kulakowski, D.: Changes of forest cover and disturbance regimes in the mountain forests of the Alps, For. Ecol. Manage., 388, 43-56, 2017.

Blahut, J., Klimeš, J., Balek, J., Hájek, P., Červená, L., and Lysák, J.: Snow avalanche hazard of the Krkonoše National Park, Czech Republic, J. Maps, 13, 86-90, 2017.

Braam, R. R., Weiss, E. E. J., and Burrough, P. A.: Spatial and temporal analysis of mass movement using dendrochronology, Catena, 14, 573-584, 1987.

Brang, P., Schönenberger, W., Frehner, M., Schwitter, R., Thormann, J. J., and Wasser, B.: Management of protection forests in the European Alps: an overview, For. Snow Landsc. Res., 80, 23-44, 2006.

Bühler, Y., Kumar, S., Veitinger, J., Christen, M., Stoffel, A., and Snehmani: Automated identification of potential snow avalanche release areas based on digital elevation models, Nat. Hazards Earth Syst. Sci., 13, 1321-1335, https://doi.org/10.5194/nhess13-1321-2013, 2013.

Campbell, C., Bakermans, L., Jamieson, B., and Stethem, C.: Current and future snow avalanche threats and mitigation measures in Canada, Canadian Avalanche Centre, Revelstoke, BC, 2007.

Casteller, A., Christen, M., Villalba, R., Martínez, H., Stöckli, V., Leiva, J. C., and Bartelt, P.: Validating numerical simulations of snow avalanches using dendrochronology: the Cerro Ventana event in Northern Patagonia, Argentina, Nat. Hazards Earth Syst. Sci., 8, 433-443, https://doi.org/10.5194/nhess-8433-2008, 2008. 
Casteller, A., Villalba, R., Mayer, A., and Stöckli, V.: Dendrochronological reconstruction of spatial and temporal patterns of snow avalanches in the Patagonian Andes, Rev. Chil. Hist. Nat., 82, 245-264, 2009.

Casteller, A., Villalba, R., Araneo, D., and Stöckli, V.: Reconstructing temporal patterns of snow avalanches at Lago del Desierto, southern Patagonian Andes, Cold Reg. Sci. Technol., 67, 68-78, 2011.

Casteller, A., Stoffel, M., Crespo, S., Villalba, R., Corona, C., and Bianchi, E.: Dendrogeomorphic reconstruction of debris-flow activity in the Patagonian Andes, Geomorphology, 228, 116-123, 2015.

Christen, M., Kowalski, J., and Bartelt, P.: RAMMS: Numerical simulation of dense snow avalanches in three-dimensional terrain, Cold Reg. Sci. Technol., 63, 1-14, 2010.

Cordero D., Casteller, A., Podvin, K., Buchholz, A., and Jiménez, M. C.: Ecosystems Protecting Infrastructure and Communities (EPIC), Chile Baseline Report, 36 pp., 2014.

Corominas, J. and Moya, J.: Contribution of dendrochronology to the determination of magnitude-frequency relationships for landslides, Geomorphology, 124, 137-149, 2010.

Cortés Donoso, E.: Local perception of the Ecosystem Services of the native forest in Las Trancas, Biobío Region, Chile, IUCN report, 29 pp., 2017.

De Quervain, M.: Wald und Lawinen, in: Proceedings of the IUFRO Seminar Mountain Forests and Avalanches, Davos, Switzerland, 219-231, 1978.

Dixon, H. J., Murphy, M. D., Sparks, S. J., Chavez, R., Naranjo, J. A., Dunkley, P. N., Young, S. R., Gilbert, J. S., and Pringle, M. R.: The geology of Nevados de Chillán volcano, Chile, Revista geológica de Chile 26, 227-253, 1999.

Donoso, C.: Bosques templados de Chile y Argentina. Variación, estructura y dinámica, Santiago de Chile, Chile, University Press, 1993.

Dorren, L. K., Maier, B., Putters, U. S., and Seijmonsbergen, A. C.: Combining field and modelling techniques to assess rockfall dynamics on a protection forest hillslope in the European Alps, Geomorphology, 57, 151-167, 2004.

Dubé, S., Filion, L., and Hétu, B.: Tree-ring reconstruction of highmagnitude snow avalanches in the northern Gaspé Peninsula, Québec, Canada, Arct. Antarc. Alp. Res., 36, 555-564, 2004.

Espinosa, G. A., Fuentes, E. R., and Hajek, E. R.: Los deslizamientos de tierras en Chile, Convenio ONEMI - PUC, Santiago de Chile, Chile, 15 pp., 1983.

ESRI (Environmental Systems Research Institute): ArcGIS 10.2, Redlands, California (1995-2013), 2013.

Estrella, M. and Saalisma, N.: Ecosystem-based disaster risk reduction (Eco-DRR): An overview, in: The role of ecosystems in disaster risk reduction, edited by: Renaud, F. G., Sudmeier-Rieux, K., and Estrella, M., UNU Press, Tokyo, 26-54, 2013.

Feistl, T., Bebi, P., Teich, M., Bühler, Y., Christen, M., Thuro, K., and Bartelt, P.: Observations and modeling of the braking effect of forests on small and medium avalanches, J. Glaciol., 60, 124$138,2014$.

Feistl, T., Bebi, P., Christen, M., Margreth, S., Diefenbach, L., and Bartelt, P.: Forest damage and snow avalanche flow regime, Nat. Hazards Earth Syst. Sci., 15, 1275-1288, https://doi.org/10.5194/nhess-15-1275-2015, 2015.
Feistl, T., Fischer, A., Bebi, P., and Bartelt, P.: Evaluation of protection measures against avalanches in forested terrain, in: Proceedings of the International Snow Science Workshop 2016, Breckenridge, CO, 2 to 7 October 2016, ISSW 16, Proceedings Volume, Breckenridge, 561-568, 2016.

Fliri, F.: Naturchronik von Tirol: Tirol, Oberpinzgau, Vorarlberg, Trentino: Beitrage zur Klimatographie von Tirol, Universitätsverlag Wagner, Innsbruck, 369 pp., 1998.

Freiberg, H. M.: Entwicklung von Böden und Vegetation an südchilenischen Vulkanen, Biogeographica, 19, 211-222, 1984.

Gądek, B., Kaczka, R. J., Rączkowska, Z., Rojan, E., Casteller, A., and Bebi, P.: Snow avalanche activity in Żleb Żandarmerii in a time of climate change (Tatra Mts., Poland), CATENA, 158, 201-212, 2017.

Gauer, P. and Kristensen, K.: Four decades of observations from NGI's full-scale avalanche test site Ryggfonn - Summary of experimental results, Cold Reg. Sci. Technol., 125, 162-176, 2016.

Germani, G.: Mass immigration and modernization in Argentina, Stud. Comp. Int. Dev., 2, 165-182, 1966.

Getzner, M., Gutheil-Knopp-Kirchwald, G., Kreimer, E., Kirchmeir, H., and Huber, M.: Gravitational natural hazards: Valuing the protective function of Alpine forests, For. Policy Econ., 80, 150-159, 2017.

González, M., Lara, A., Urrutia R., and Bosnich, J.: Climatic change and its potential impact on forest fire occurrence in south-central Chile $\left(33^{\circ}-42^{\circ} \mathrm{S}\right)$, Bosque, 32, 215-219, 2011.

Holmes, R. L.: COFECHA - Computer-assisted quality control in tree-ring dating and measurement, Tree-ring Bull., 43, 69-78, 1983.

La Discusión: Trabajador que despejaba camino a las Termas de Chillán murió tras producirse avalancha, available at: http://www.emol.com/noticias/nacional/2011/07/16/492942 (last access: 11 March 2017), 2011.

Laely, A.: Davoser Heimatkunde. Beiträge zur Geschichte der Landschaft Davos, 2. Auflage, Verlag Genossenschaft Davoser Revue, Davos, 275 pp., 1984.

Lara, A., Soto, D., Armesto, J., Donoso, P., Wernli, C., Nahuelhual, L., and Squeo, F. (Eds.): Componentes Científicos Clave para una Política Nacional Sobre Usos, Servicios y Conservación de los Bosques Nativos Chilenos, Libro resultante de la Reunión Científica sobre Bosques Nativos, Valdivia, Chile, Universidad Austral de Chile, Iniciativa Científica Milenio de Mideplan, 111 pp., 2003.

Luebert, F. and Pliscoff, P.: Sinopsis bioclimática y vegetacional de Chile, Editorial Universitaria, 2006.

Lundberg, A., Nakai, Y., Thunehed, H., and Halldin, S.: Snow accumulation in forests from ground and remote-sensing data, Hydrol. Process., 18, 1941-1955, 2004.

Maggioni, M. and Gruber, U.: The influence of topographic parameters on avalanche release dimension and frequency, Cold Reg. Sci. Technol., 37, 407-419, 2003.

McBreen, J.: Regional Assessment on Ecosystem-based Disaster Risk Reduction and Biodiversity in South America, A report for the Resilience through Investing in Ecosystems - knowledge, innovation and transformation of risk management (RELIEF Kit) project, International Union for Conservation of Nature, Quito, Ecuador, 2016. 
Mundo, I. A., Barrera, M. D., and Roig, F. A.: Testing the utility of Nothofagus pumilio for dating a snow avalanche in Tierra del Fuego, Argentina, Dendrochronologia, 25, 19-28, 2007.

Mundo, I. A., Kitzberger, T., Juñent, F. R., Villalba, R., and Barrera, M. D.: Fire history in the Araucaria araucana forests of Argentina: human and climate influences, Int. J. Wildland Fire, 22, 194-206, 2013.

Olschewski, R., Bebi, P., Teich, M., Hayek, U. W., and GrêtRegamey, A.: Avalanche protection by forests - A choice experiment in the Swiss Alps, For. Policy Econ., 17, 19-24, 2012.

Panayotov, M., Kulakowski, D., Laranjeiro Dos Santos, L., and Bebi, P.: Wind disturbances shape old Norway spruce-dominated forest in Bulgaria, For. Ecol. Manage., 262, 470-481, 2011.

Pfanzelt, S., Grau, J., and Rodríguez, R.: A vegetation map of Nevados de Chillan volcanic complex, Bío-Bío Region, Chile, Gayana Bot 65, 209-219, 2008.

Pop, O. T., Gavrilă, I. G., Roşian, G., Meseşan, F., Decaulne, A., Holobâcă, I. H., and Anghel, T.: A century-long snow avalanche chronology reconstructed from tree-rings in Parâng Mountains (Southern Carpathians, Romania), Quat. Int., 415, 230-240, 2016.

Price, M. F. and Thompson, M.: The complex life: human land uses in mountain ecosystems, Glob. Ecol. Biogeogr. Lett., 6, 77-90, 1997.

R Core Team: R: A language and environment for statistical computing, R Foundation for Statistical Computing, Vienna, Austria, 2014.

Renaud, F. G., Sudmeier-Rieux, K., and Estrella, M.: The role of ecosystems in disaster risk reduction, United Nations University Press, 440 pp., 2013.

Riebsame, W. E., Gosnell, H., and Theobald, D. M.: Land use and landscape change in the Colorado mountains I: Theory, scale, and pattern, Mt. Res. Dev., 6, 395-405, 1996.

Romero, H. and Ordenes, F.: Emerging urbanization in the Southern Andes: environmental impacts of urban sprawl in Santiago de Chile on the Andean piedmont, Mt. Res. Dev., 24, 197-201, 2004.

San Martín, P.: Reserva de la Biosfera Corredor Biológico Nevados de Chillán - Laguna del Laja: de la amenaza de la extinción al desarrollo sustentable, in: Reservas de la Biosfera de Chile: Laboratorios para la Sustentabilidad, edited by: Moreira-Muñoz, A. and Borsdorf, A., Academia de Ciencias Austríaca, Pontificia Universidad Católica de Chile, Instituto de Geografía, Santiago, serie Geolibros, 17, 146-160, 2014.

Schönenberger, W.: Cluster afforestation for creating diverse mountain forest structures - a review, For. Ecol. Manage., 145, 121128, 2001.

Shroder, J. F.: Dendrogeomorphological analysis of mass movement on Table Cliffs Plateau, Utah, Quat. Res., 9, 168-185, 1978.
Shroder Jr., J. F.: Dendrogeomorphology: review and new techniques of tree-ring dating, Prog. Phys. Geogr., 4, 161-188, 1980.

Soil Survey Staff: Soil taxonomy, Twelfth Edition, USDA, Washington DC, USA, 2014.

Stoffel, M. and Corona, C.: Dendroecological dating of geomorphic disturbance in trees, Tree-Ring Res., 70, 3-20, 2014.

Stoffel, M. and Huggel, C.: Effects of climate change on mass movements in mountain environments, Prog. Phys. Geogr., 36, 421-439, 2012.

Stoffel, M., Bollschweiler, M., and Hassler, G. R.: Differentiating past events on a cone influenced by debris-flow and snow avalanche activity - a dendrogeomorphological approach, Earth Surf. Proc. Land., 31, 1424-1437, 2006.

Stoffel, M., Casteller, A., Luckman, B. H., and Villalba, R.: Spatiotemporal analysis of channel wall erosion in ephemeral torrents using tree roots - an example from the Patagonian Andes, Geology, 40, 247-250, 2012.

Stokes, M. A. and Smiley, T. L.: An introduction to Tree-Ring Dating, University of Chicago Press, Chicago, 73 pp., 1968.

Su, S., Jiang, Z., Zhang, Q., and Zhang, Y.: Transformation of agricultural landscapes under rapid urbanization: a threat to sustainability in Hang-Jia-Hu region, China, Appl. Geogr., 31, 439-449, 2011.

Takeuchi, Y., Torita, H., Nishimura, K., and Hirashima, H.: Study of a large-scale dry slab avalanche and the extent of damage to a cedar forest in the Makunosawa valley, Myoko, Japan, Ann. Glaciol., 52, 119-128, 2011.

Teich, M., Bartelt, P., Grêt-Regamey, A., and Bebi, P.: Snow avalanches in forested terrain: Influence of forest parameters, topography, and avalanche characteristics on runout distance, Arct. Antarc. Alp. Res., 44, 509-519, 2012.

Valero, C. V., Wever, N., Bühler, Y., Stoffel, L., Margreth, S., and Bartelt, P.: Modelling wet snow avalanche runout to assess road safety at a high-altitude mine in the central Andes, Nat. Hazards Earth Syst. Sci., 16, 2303-2323, https://doi.org/10.5194/nhess16-2303-2016, 2016.

Viglietti, D., Letey, S., Motta, R., Maggioni, M., and Freppaz, M.: Snow avalanche release in forest ecosystems: A case study in the Aosta Valley Region (NW-Italy), Cold Reg. Sci. Technol., 64, 167-173, 2010.

Weir, P.: Snow Avalanche Management in Forested Terrain, Victoria, British Columbia: Research Branch, British Columbia Ministry of Forests, Land Management Handbook, 55, 190 pp., 2002.

Wisner, B., Blaikie, P., Cannon, T., and Davis, I.: At risk: Natural hazards, people's vulnerabilities and disasters, Routledge, London, 471 pp., 2004. 